\title{
Immunohistochemical and Histopathological Changes in the Skin of Rats after Administration of Lead Acetate
}

\author{
Alteraciones Inmunohistoquímicas e Histopatológicas en la Piel \\ de Ratas tras la Administración de Acetato de Plomo
}

Bilal Sula*; Engin Deveci**; Hüseyin Özevren ${ }^{* * * *}$; Cenap Ekinci** ${ }^{* *}$ Bilal Elbey $^{\text {**** }}$

SULA, B.; DEVECI, E.; ÖZEVREN, H.; EKINCI, C. \& ELBEY, B. Immunohistochemical and histopathological changes in the skin of rats after administration of lead acetate. Int. J. Morphol., 34(3):918-922, 2016.

SUMMARY: Lead acetate is a chemical compound. Sources of human exposure to this metal include many foods, drinking water and dust. The aim of this study was to determine the immunohistochemical and histopathological changes on the face skin after lead acetate application. Wistar Albino rats (180-200 g body weight) were divided into a controlled and lead acetate-exposed group. Rats received lead acetate at $500 \mathrm{ppm}$ in their drinking water for 60 days. Both groups were fed with the same standard food, but lead acetate was added to the drinking water. During the experimental period, blood samples were drawn from the abdominal aorta of the anesthetised animals. At the end of exposure, body weight and blood lead levels were measured. Sections of rat facial skin were examined histopathological and immunohistochemical. In the group treated with lead acetate, minimal to slight multifocal hydropic degeneration of basal cell layer, depending on the thinning of the epidermis, the cellular degeneration in the dermis and a increase in the number of necrotic cells was observed in sebaceous glands of the hair follicle hemorrhage. The immunohistochemical results of the present work demonstrated an increase in Proliferating cell nuclear antigen (PCNA) immunoreactivity in skin specimens from lead acetate treated animals. Vimentin immunoreactivity was very dense in hair follicle of the subepidermal region. It was also strongly stained around the myoepithelial cells surrounding sebaceous and stromal cells.

KEY WORDS: Lead acetate; Skin; Proliferating cell nuclear antigen; Vimentin.

\section{INTRODUCTION}

Lead exposure damages mainly the central nervous system and organs such as the liver, kidneys, hematopoietic system, and reproductive system via inhalation, oral ingestion, and skin contact, consequently having an adverse impact on health (Cohen \& Roe, 1991; IARC Working Group on the Evaluation of Carcinogenic Risks to Humans, 2006). Sources of human exposure to this metal include many foods, drinking water, and dust (El-Nekeety et al., 2009). Pregnant women, children, and city inhabitants are at risk of lead intoxication. Lead induces a broad range of physiological and biochemical dysfunctions (Sivaprasad et al., 2004). The mechanism of lead-induced oxidative stress involves an imbalance between generation and removal of ROS (reactive oxygen species) in tissues and cellular components causing damage to membranes, DNA and proteins (Harte et al., 1991; Paltra et al., 2011). Sweat, hair and nail loss and desquamation have been characterized as important modes of lead detoxification (Lilley et al., 1988). Lead has been found in the hair root (having been delivered via radial transcellular transport) and in increasing amounts along the hair shaft indicating exogenous origin (Guy et al., 1999).

Proliferating cell nuclear antigen (PCNA) is a nuclear protein that is synthesized in late $\mathrm{G} 1$ and $\mathrm{S}$ phases of the cell cycle and is, therefore, correlated with the cell proliferative state (Woods et al., 1999). Vimentin filaments are more broadly distributed among tissues such as in the cells of the mesenchymal origin (Fu \& Boffetta, 1995). The aim of this study was to determine the immunohistochemical and histopathological changes on the face skin after lead acetate application.

\footnotetext{
"Department of Dermatology, Faculty of Medicine, Dicle University, Diyarbakır, Turkey.

** Department of Histology and Embryology, Faculty of Medicine, Dicle University, Diyarbakır, Turkey.

*** Department of Immunology, Faculty of Medicine, Dicle University, Diyarbakır, Turkey.
} 


\section{MATERIAL AND METHOD}

Wistar rats (9 weeks old, $180-200 \mathrm{~g}$ body weight) used in these trials were divided into two groups of 30 animals each (control group and experimental group). Animals of the experimental group were given drinking water containing $500 \mathrm{ppm}$ lead acetate for a period of 2 months. The rats were obtained from the Department of Medical Science Application and Research Centre of Dicle University. All the animals were individually housed in stainless steel cages at room temparature. The animals had free access to standard laboratory rat pellet and water. The face skin were dissected under ketamine hidrochloride anesthesia and placed in $10 \%$ formaldehide solution. They were placed in parafine inclusion melted at $58{ }^{\circ} \mathrm{C}$ after treatment with xylol, the 4-6 $\mu \mathrm{m}$ sections were taken by rotary microtome and the sections were stained with Hematoxylene-Eosin (H-E) and then observed under Olympus BH2 light microscopy to determine histological changes.

Immunohistochemical staining. The tissues were put into a formalin solution for fixation and then embedded in paraffin wax. Then they were cut into 4-6 $\mathrm{mm}$ sections on positively charged glass slides. Sections were deparaffinized with xylene, followed by immersion in graded alcohol for dehydration and incubation with EDTA $(\mathrm{pH}=8.0$, Merck, Germany) for $5+4+3 \mathrm{~min}$ in a microwave oven $(750 \mathrm{~W}$ ) for antigen retrieval. Next, sections were incubated for $20 \mathrm{~min}$ in $3 \% \mathrm{H}_{2} \mathrm{O}_{2} /$ Methanol to block endogenous peroxidase activity, then rinsed in phosphate-buffered saline (PBS) for 5 min three times. The sections were later incubated with a blocking solution (normal goat serum, Invitrogen, Carlsbad, CA). Slides were then incubated overnight with primary antibodies, PCNA Antibody (PC10) (Santa Cruz, 1/100, mouse monoclonal) and type and Vimentin (Santa Cruz, 1/ 200, mouse monoclonal). After washing in PBS, the sections were treated with labeled-streptavidin kits (Invitrogen, Carlsbad, CA). The reaction was visualized by incubating the sections for $7 \mathrm{~min}$ in a $0.1 \% 3,3$ diaminobenzidine and $0.02 \%$ hydrogen peroxide solution (DAB substrate kit, Invitrogen, Carlsbad CA). Finally, the sections were counterstained with Hematoxylin (Sigma) and covered. Immunohistochemistry positive staining was defined as the presence of a brown color detection chromogen (DAB) on the edge of the hematoxylin-stained cell nucleus distributed within the cytoplasm or plasma membrane of the cells and assessed by light microscope.

Blood sample collection. The animals were anesthetised with diethylether and blood samples were collected via intracardiac puncture using heparin as anticoagulant. Whole blood samples were maintained at $48{ }^{\circ} \mathrm{C}$ for blood concentration. Blood lead levels were analyzed using an atomic absorption spectrophotometer (Deveci, 2006).

Statistics. The experimental data were evaluated by means of the Student's t-test. The blood values were expressed. The effects on body weight of a rat were exposed to 500 ppm lead acetate in drinking water. The blood lead values were expressed as $\mathrm{mg} / \mathrm{dL}$ of whole blood (Deveci).

\section{RESULTS}

In our study, histopathologic comparison between the sections of the control group and experimental group subjected to lead acetate was made (Table I). Body weights of lead exposed group declined progressively with significant decline for a period of 2 months of lead exposure $(p<0.05)$ in comparison to control rats. Blood lead level of rats after prolonged consumption of water enriched with lead acetate significantly exceeded those observed in controls and reached $28.40 \mathrm{mg} / \mathrm{dL}$. After 60 days of exposure to lead acetate, a significant increase of lead concentration was observed in the blood ( $\mathrm{p}<0.01$ ) (Table I). Experimental group and the control group epidermis thickness and diameter of the hair follicles were compared (Table II).

Histological analysis of rat skin samples in the control group with H-E staining revealed normal epidermis and dermis layers of the skin (Fig. 1A). The epidermis was composed of stratified squamous epithelium and was seen in its normal thickness. The underlying papillary layer of the dermis had abundant capillaries and connective tissue cells, whereas the reticular layer of the dermis was composed

Table I. Body Weight and Blood Value.

\begin{tabular}{lcc}
\hline Group & Body weight & Blood mg/dL \\
\hline Control $(\mathrm{n}=10)$ & $200.30 \pm 3.70$ & $1.82 \pm 1.05$ \\
Experimental $(\mathrm{n}=10)$ & $160.20 \pm 4.05$ & $28.40 \pm 1.04$ \\
\hline
\end{tabular}

Table II. Comparison of epidermis thickness and diameter of the hair follicles

\begin{tabular}{lccc}
\hline & $\begin{array}{c}\text { Control group } \\
(\mathbf{M e a n} \pm \mathbf{S D})\end{array}$ & $\begin{array}{c}\text { Experimental group } \\
(\mathbf{M e a n} \pm \text { SD })\end{array}$ & $\boldsymbol{p}$ \\
\hline Epidermal thickness & $10.08 \pm 2.61$ & $8.13 \pm 2.03$ & 0.028 \\
Hair follicle diameter & $1279.03 \pm 327.49$ & $625.74 \pm 179.54$ & $<0.001$ \\
\hline
\end{tabular}




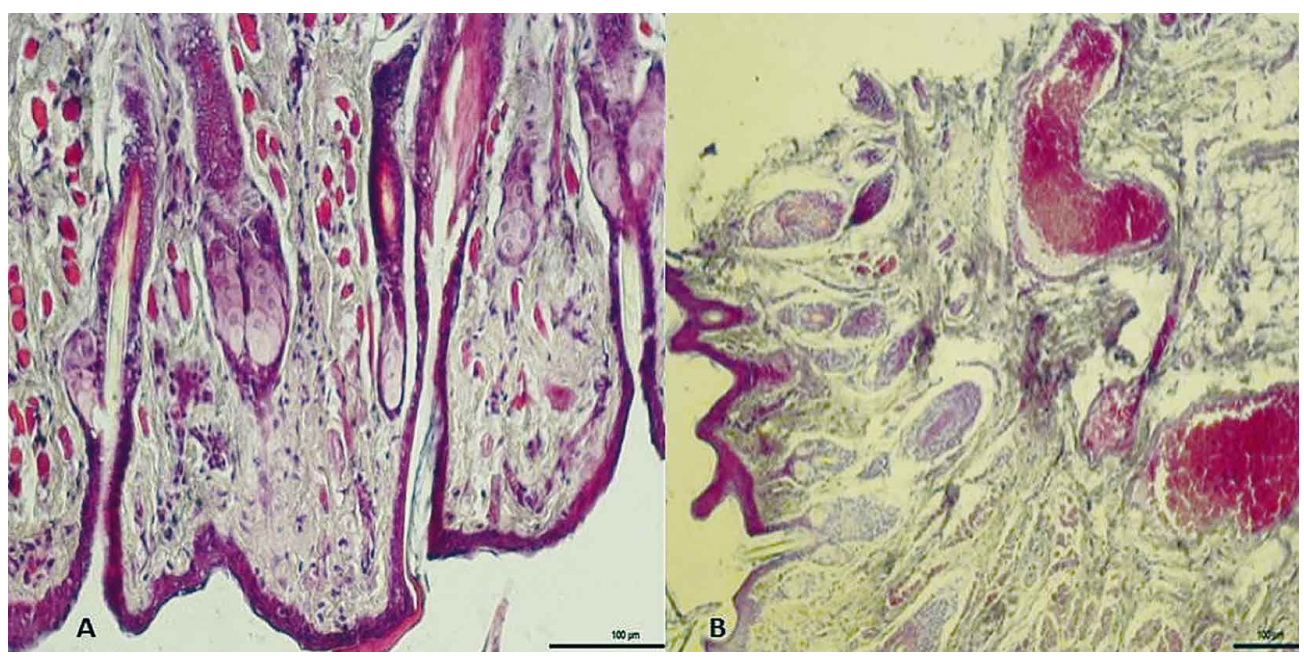

Fig. 1. A) Control group: Epidermis and dermis were seen to have normal histological appearance (H-E, Bar $100 \mu \mathrm{m})$. B) Experimental group: Degeneration and necrosis in epidermis and degenerative changes in hair follicles, a decresae in collagen bundles, mononuclear cell infiltration, apoptotic changes in stromal cells, vasodilation and congestion in dermis and hypodermis (H-E staining, Bar $100 \mu \mathrm{m}$ ).

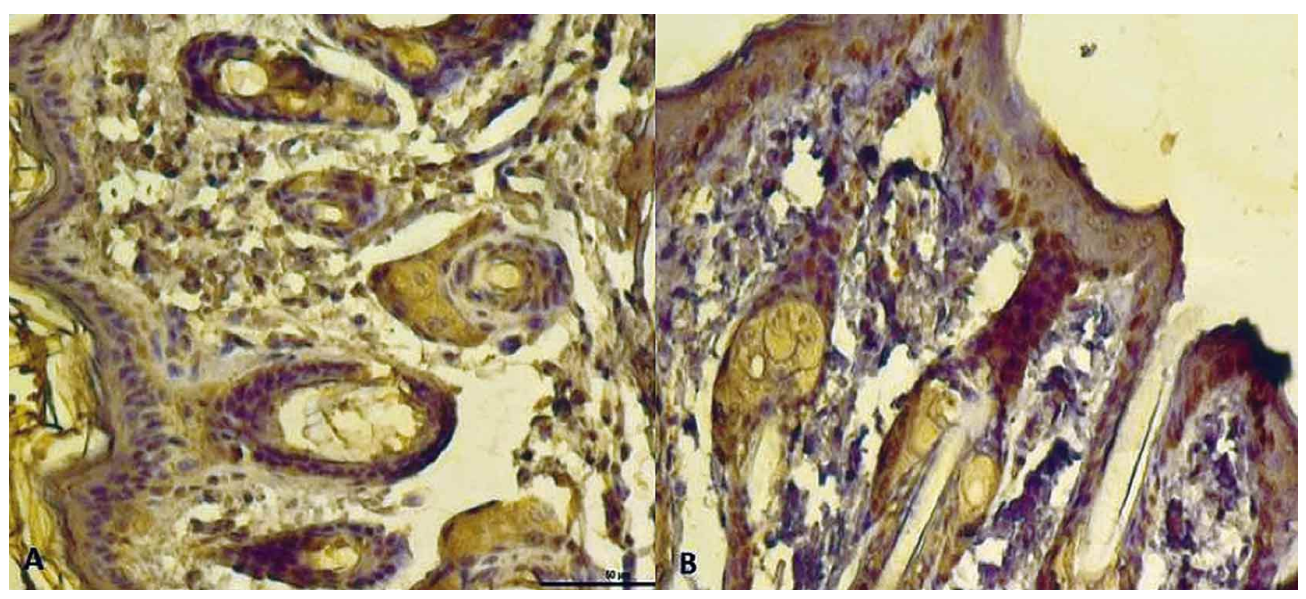

Fig. 2. A) Control group: Weak PCNA expression in the epidermis, some expression in hair follicles and sebaceous glands positive basolateral compartment in dermis (PCNA immun-staining, Bar $50 \mu \mathrm{m}$ ). B) Experimental group: Increase in PCNA expression in cells of the apical and basal layer in the epidermis, PCNA positive expression in the basal layer and hair follicles (PCNA immun-staining, Bar $100 \mu \mathrm{m}$ ).

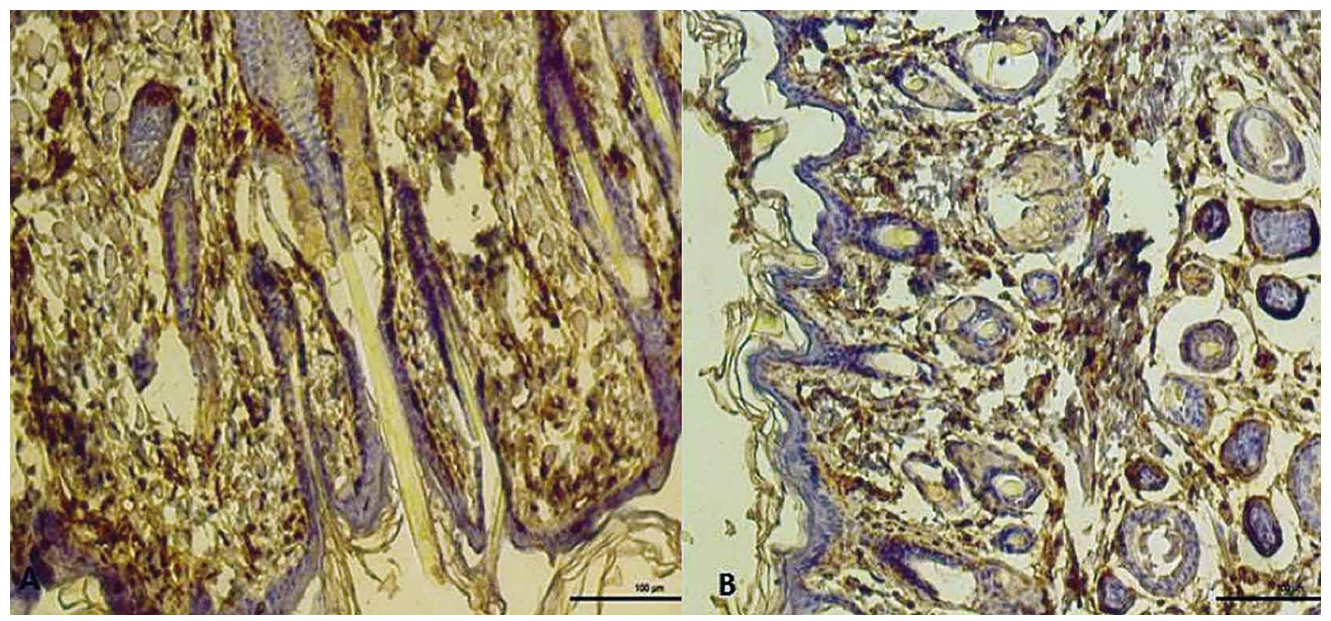

of a dense connective tissue rich in collagen fibers. In the group treated with lead acetate, minimal to slight multifocal hydropic degeneration of basal cell layer, depending on the thinning of the epidermis, the cellular degeneration in the dermis and an increase in the number of necrotic cells was observed in sebaceous glands of the hair follicle hemorrhage. Infiltration of inflammatory cells such as neutrophils, eosinophils, monocytes and hypertrophy of the epidermis were evident (Fig. 1B). There was also increased keratinization of the epidermis in the apical cell degeneration. In this study, the immunohistochemical results of the present work demonstrated an increase in PCNA immunoreactivity in skin specimens from lead acetate treated animals. It was reported that the

Fig. 3. A) Control group: Some hair follicles and sebaceous glands in the dermis fibroblast cells with vimentin expression in some cells around the myoepithelial cell positive (Vimentin immun-staining, Bar $100 \mu \mathrm{m}$ ). B) Experimental group: A decrease in vimentin expression around the hair follicles and sebaceous glands, vimentin positive expression in fibroblasts and muscle cells around blood vessels in the dermis (Vimentin immun-staining, Bar $100 \mu \mathrm{m})$. 
hyperproliferative epidermis is characterized by an increased number of proliferating cells expressing PCNA (Fig. 2). In the group treated with lead acetate; Vimentin immunoreactivity was very dense in hair follicle of the subepidermal region. It was also strongly stained around the myoepithelial cells surrounding sebaceous and stromal cells. Vimentin-immunoreactivity was observed in the fibroblasts, endothelial cells of vessels and of some hair follicles. Vimentin-immunoreactivity was very dense in the smooth muscle cells of blood vessels, it was positively stained in the arrectores pilorum muscles (Fig. 3).

\section{DISCUSSION}

Lead acetate is a chemical compound. It is hazardous when swallowed, inhaled or absorbed through the skin. Humans get lead into their body systems through the gastrointestinal tract, respiratory tracts and occasionally through the skin (Neathery \& Miller, 1975). Lead exposure can occur from contact with lead in air, household dust, soil, water and commercial products (Rossi, 2008). Lead acetate may be absorbed through the skin on prolonged exposure; the symptoms of lead poisoning described for ingestion exposure may ocur. Mestek et al. (1998) varying doses were given to experimental animals into drinking water by adding lead acetate. Such as skin, nails and tendons stressed that the collagen-rich tissues from lead acetate accumulation and influence. In our study, a reduction in fibrillar collagen, the dilatation of the blood vessels, hemorrhage and mononuclear cell infiltration was observed. Degeneration and increased keratinization were also observed in the surface epithelium. Sweat, hair, nail loss and desquamation have been charecterized as important modes of lead detoxification (Lilley et al.). Lead has been found in the hair root (having been delivered via radial transcellular transport) and in increasing amount along the hair shaft indicating exogenous origin (Guy et al.). In our study, as a proliferation marker PCNA damaged skin stained with normal skin stronger. Lead acetate applications abnormal differentiation of epidermal keratinocytes, the hair follicles and sebaceous glands has been shown to increase in apoptotic cells. Heid et al. (1988) reported vimentin immunoreactivity in the hair follicle bulbus of mammalian skin. Mesenchymal tissues, especially in the connective tissue of a vimentin intermediate filament protein expressed in the dermal sheath of hair follicles are increased. Also supporting the hair follicle is an essential element. Vimentinimmunoreactivity was seen in the dermal stromal cells in which their processes extended into the hair follicle and sebaceous glands. Vimentin in the dermal sheath is observed at all follicle heights and is often abundant in the dermal papilla. Lead acetate group in our study, vimentin expression in the dermal papilla hair follicles and sebaceous glands showed a reduction. Vimentin, provides the support of hair follicles, sebaceous glands and helps the development of smooth muscle. It is thought that this support weakens the effect of lead acetate.

\section{CONCLUSIONS}

As a result; In our study, lead acetate by effector cells in the epidermis the formation of new cells have been shown to disrupt. Expression of PCNA positive apoptotic cells in the basal layer and hair follicles was evaluated as an indication of this effect. The reduction in hair follicles and sebaceous glands around the hair can affect the development of the dermis and is thought to be the cause for the decline.

SULA, B.; DEVECI, E.; ÖZEVREN, H.; EKINCI, C. \& ELBEY, B. Alteraciones inmunohistoquímicas e histopatológicas en la piel de ratas tras la administración de acetato de plomo. Int. J. Morphol., 34(2):918-922, 2016.

RESUMEN: El acetato de plomo es un compuesto químico. Las fuentes de exposición humana a este metal incluyen una gran variedad de alimentos, agua potable y el polvo. El objetivo fue determinar los cambios inmunohistoquímicos e histopatológicos en la piel de la cara después de la aplicación de acetato de plomo en ratas Wistar albinas (180 a $200 \mathrm{~g}$ de peso corporal) las que fueron divididas en un grupo control y otro expuesto al acetato de plomo. Las ratas expuestas recibieron acetato de plomo en dosis de 500 ppm en el agua que bebían durante 60 días. Ambos grupos fueron alimentados con el mismo pellet estándar. Durante el período experimental, se extrajeron muestras de sangre desde la parte abdominal de la aorta con los animales anestesiados. Al final de la exposición, se midió el peso corporal y los niveles de plomo en la sangre. Secciones de piel de la cara se examinaron y estudiaron con procediminetos histopatológicos e inmunohistoquímicos. En el grupo expuesto, se observó una degeneracion hidrópica multifocal desde mínima a ligera de la capa de células basales; dependiendo del adelgazamiento de la epidermis, se observó degeneración celular en la dermis y un aumento en el número de células necróticas en las glándulas sebáceas de folículos pilosos hemorrágicos. Los resultados inmunohistoquímicos demostraron un aumento de inmunoreactividad al antígeno nuclear de células en proliferación (PCNA) en las muestras de piel de los animales tratados con acetato de plomo. La inmunoreactividad a vimentina fue muy densa en los folículos pilosos de la región subepidermal. También se observó una fuerte tinción alrededor de las células mioepiteliales que rodean las células sebáceas y estromales.

PALABRAS CLAVE: Acetato de plomo; Piel; Antígeno nuclear de células en proliferación; Vimentina. 


\section{REFERENCES}

Cohen, A. J. \& Roe, F. J. Review of lead toxicology relevant to the safety assessment of lead acetate as a hair colouring. Food Chem. Toxicol., 29(7):485-507, 1991.

Deveci, E. Ultrastructural effects of lead acetate on brain of rats. Toxicol. Ind. Health, 22(10):419-22, 2006.

El-Nekeety, A. A; El-Kady, A. A; Soliman, M. S.; Hassan, N. S. \& Abdel-Wahhab, M. A. Protective effect of Aquilegia vulgaris (L.) against lead acetate-induced oxidative stress in rats. Food Chem. Toxicol., 47(9):2209-15, 2009.

Fu, H. \& Boffetta, P. Cancer and occupational exposure to inorganic lead compounds: a meta-analysis of published data. Occup. Environ. Med., 52(2):73-81, 1995.

Guy, R. H.; Hostynek, J. J.; Hinz, R. S. \& Lorence, C. R. Metals and the Skin. Topical Effects and Systemic Absorption. Chapter 27. New York, Marcel Dekker, Inc., 1999. pp.331.

Harte, J.; Holdre, C. \& Shirley, C. Toxics A to Z. A Guide to Everyday Pollution Hazards. Berkeley, University of California Press, 1991. pp.47-104.

Heid, H. W.; Moll, I. \& Franke, W. W. Patterns of expression of trichocytic and epithelial cytokeratins in mammalian tissues. I. Human and bovine hair follicles. Differentiation, 37(2):137$57,1988$.

IARC Working Group on the Evaluation of Carcinogenic Risks to Humans. Inorganic and organic lead compounds. IARC Monogr. Eval. Carcinog. Risks Hum., 87:1-471, 2006.

Lilley, S. G.; Florence, T. M. \& Stauber, J. L. The use of sweat to monitor lead absorption through the skin. Sci. Total Environ., 76(2-3):267-78, 1988 .

Mestek, O.; Deyl, Z.; Miksík, I.; Novotná, J.; Pfeifer, I. \& Herget, J. Accumulation of lead in tissues after its administration in drinking water to laboratory rats. Physiol. Res., 47(3):197-202, 1998.

Neathery, M. W. \& Miller, W. J. Metabolism and toxicity of cadmium, mercury, and lead in animals: a review. J. Dairy Sci., 58(12):1767-81, 1975.

Patra, R. C.; Rautray, A. K. \& Swarup, D. Oxidative stress in lead and cadmium toxicity and its amelioration. Vet. Med. Int., 2011:457327, 2011.

Rossi, E. Low level environmental lead exposure--a continuing challenge. Clin. Biochem. Rev., 29(2):63-70, 2008.

Sivaprasad, R.; Nagaraj, M. \& Varalakshmi, P. Combined efficacies of lipoic acid and 2,3-dimercaptosuccinic acid against lead- induced lipid peroxidation in rat liver. J. Nutr. Biochem., 15(1):18-23, 2004.

Woods, A. L.; Hall, P. A.; Shepherd, N. A.; Hanby, A. M.; Waseem, N. H.; Lane, D. P. \& Levison, D. A. The assessment of proliferating cell nuclear antigen (PCNA) immunostaining in primary gastrointestinal lymphomas and its relationship to histological grade, $\mathrm{S}+\mathrm{G} 2+\mathrm{M}$ phase fraction (flow cytometric analysis) and prognosis. Histopathology, 19(1):21-7, 1991.

\author{
Correspondence to: \\ Engin Deveci \\ Department of Histology and Embryology \\ Faculty of Medicine \\ Dicle University \\ Diyarbakir \\ TURKEY
}

Email: engindeveci64@gmail.com

Received: 23-02-2016

Accepted: 15-04-2016 